\title{
Vulvovaginal candidosis caused by Candida Non-Albicans, proportion and clinical characteristics in the Dr. Cipto Mangunkusumo National General Hospital, Jakarta
}

\author{
Midi Haryani*, Kuswadji S. Urip, ${ }^{f}$ Sjarif M. Wasitaatmadja ${ }^{\infty}$
}

\begin{abstract}
Abstrak
Angka kejadian Kandidosis vulvovaginalis (KVV) yang disebabkan C.non-albicans belakangan ini cenderung meningkat. Namun di RSCM, sampai saat ini belum ada data tentang proporsi dan karakteristik KVV yang disebabkan C.non-albicans. Untuk itu dilakukan penelitian deskriptif dengan rancangan studi potong lintang. Subyek penelitian adalah wanita yang datang ke Poliklinik Kulit dan Kelamin serta Poliklinik Kebidanan dan Kandungan RSCM yang mengeluh keputihan dan gatal, serta pada pemeriksaan sediaan apus dengan pewarnaan Gram ditemukan blastospora dengan atau tanpa pseudohifa, tanpa infeksi genital spesifik lain. Kultur dibuat dengan menggunakan media CHROMagar Candida untuk membedakan spesies Candida penyebab. Didapatkan subyek terbanyak pada kelompok usia 26 - 44 tahun, dengan nilai tengah 29 tahun. Dari 69 subyek yang menderita KVV, sebanyak 30,4\% disebabkan oleh C.non-albicans, terdiri atas : C. glabrata (61,9\%), C. tropicalis $(28,6 \%)$ dan C. parapsilosis $(9,5 \%)$. KVV yang disebabkan oleh C.non-albicans cenderung terjadi pada pasien dengan usia lebih dari 45 tahun, menggunakan KB non-hormonal, memiliki pasangan dengan keluhan gatal dan kemerahan pada ujung penis dan keluhan terjadi lebih dari satu tahun. Tidak ditemukan perbedaan gejala klinis KVV yang disebabkan oleh C. albicans dan C. non-albicans. (Med J Indones 2003; 12: 142-7)
\end{abstract}

\begin{abstract}
The prevalence of Vulvovaginal candidosis (VVC) caused by C.non-albicans tends to increase, recently. The aim of this study was to obtain data about proportion and clinical characteristic of C.non-albicans VVC at dr. Cipto Mangunkusumo General Hospital, Jakarta. This is a cross-sectional study on all female patients with symptoms of VVC visiting Obstetri-gynaecology and Dermatovenereology outpatient clinics at Dr. Cipto Mangunkusumo General Hospital, Jakarta. All subjects had positive Gram stain, showed Candida spp. on culture with CHROMagar Candida, and had no other specific genital infections. Sixty nine subjects aged 26 - 44 years old (averaged 29 years old) were included in this study. Candida non-albicans was found in 30.4\% subject, and consisted of: C. glabrata (61.9\%), C. tropicalis (28.6\%) and C. parapsilosis (9.5\%). We found that C.non-albicans VVC infections are more common in women above 45 years old, using non-hormonal contraceptives, whose sexual partner has erythema and pruritus in glands penis, and having the disease for more than 1 year. No differences in clinical symptoms were noted between C. albicans and C.nonalbicans infection. We concluded from this study that the proportion of C. non-albicans infections at dr. Cipto Mangunkusumo General Hospital, Jakarta, with C. glabrata represents the most prevalent species. No characteristic clinical symptoms were found from the subjects with C.non-albicans VVC when compared with those infected by C. albicans. (Med J Indones 2003; 12: 142-7)
\end{abstract}

Keywords : vulvovaginal candidosis, Candida non-albicans, CHROMagar Candida

Vulvovaginal candidosis (VVC) is a mucosal infection caused by Candida spp. The estimated incidence of

\footnotetext{
* Dermatovenereology Department, Faculty of Medicine, University of Indonesia, Jakarta, Indonesia

${ }^{f}$ Mycology Division, Department of Dermatovenereology Faculty of Medicine, University of Indonesia, Jakarta, Indonesia

${ }^{\infty}$ Cosmetomedic Division, Department of Dermatovenereology Faculty of Medicine, University of Indonesia, Jakarta, Indonesia
}

VVC is 5 to $20 \%$, and 1 to $5 \%$ of cases become recurrent. ${ }^{1-4}$ Candida albicans is responsible for $80-$ $90 \%$ of VVC episodes and the rest are caused by nonalbicans species. ${ }^{5-7} \mathrm{~A}$ tendency of increasing frequency of C. non-albicans $\mathrm{VVC}$ in many places and countries has been reported as high as $2-57 \%$, recently. The most common non-albicans species are: Candida glabrata, followed by Candida tropicalis and Candida parapsilosis. ${ }^{6-10}$ 
C. non-albicans infection now becomes a medical problem, due to the increasing prevalence especially in immunocompromised patients, the emergence of newly recognized pathogens, the discovery of resistance species to anti-fungal azoles as well as recurrent infections. ${ }^{8,9,11}$ It is also suggested to be associated with inadequate treatment with broad spectrum anti-fungal.

We performed this study to obtain further data on the proportion and clinical characteristic of $C$. nonalbicans VVC in dr. Cipto mangunkusumo General Hospital, Jakarta. We hope the results of this study will help the health providers to perform optimal management of patients with VVC, especially those who do not respond to standard therapy.

\section{METHODS}

We conducted a cross-sectional study at Dr. Cipto Mangunkusumo General Hospital, Jakarta, from February to April 2002. The subjects were female patients who attended Obstetric Gynaecology and Dermatovenereology outpatient clinics. The subjects must have a distinct clinical symptoms associatiated with VVC, a positive vaginal smear with Gram stain (blastospore and or pseudohyphae), a positive Candida spp. with CHROMagar Candida culture and had no other specific genital infections. Subjects were not allowed to take any oral or topical antifungal for 2 and 4 weeks, respectively, before entering this study.

Informed consents were taken from all subjects. Epidemiological characteristics, history of illness, predisposing factors, physical examination of the external genitalia and the surrounding skin, the result of vaginal specimen with Gram stain and Candida spp. identified in CHROMagar Candida media are reported.

Data were analyzed using SPSS 10.0 for Windows and Epi Info 2000. Chi-square test or Fisher exact test were applied for data value less than 5, to compare the C. albicans versus C.non-albicans infection but not for mixed infection.

\section{RESULTS}

Sixty-nine women aged 26-44 years old (mean: 29 years) were included in this study. Fifty-seven subjects were married (82.6\%). Most of them were in the middle education group (59.4\%), and only 23 subjects had a permanent job, as a government or private employee ( $8.7 \%$ and $24.6 \%$, respectively).

Table 1. Proportion of the Candida spp as the cause of VVC

\begin{tabular}{lccc}
\hline Candida spp & $\mathrm{n}$ & $\%$ & $\begin{array}{c}\text { \% among } \\
\text { C. non albicans }\end{array}$ \\
\hline C. albicans & $\mathbf{4 3}$ & $\mathbf{6 2 . 3}$ & $\mathbf{0}$ \\
C non-albicans : & 21 & 30.4 & 0 \\
$\quad$ C. glabrata & $\mathbf{1 3}$ & $\mathbf{6 1 . 9}$ & $\mathbf{6 1 . 9}$ \\
$\quad$ C. tropicalis & 6 & 28.6 & 28.6 \\
$\quad$ C. krusei & 0 & 0.0 & 0.0 \\
$\quad$ C. parapsilosis & 2 & 9.5 & 9.5 \\
Mixed infection & 5 & 7.3 & 0 \\
\hline
\end{tabular}

$\mathrm{n}$, numbers

C. non-albicans is found in $30.4 \%$ subjects, with C. glabrata as the most common species. Mixed infection of $C$. albicans $+C$. tropicalis, and C. albicans $+C$. parapsilosis, were found in 3 and 2 subject, respectively. (Tabel 1)

Table 2 lists the history of illness and subjective findings.

Pruritus is the most frequent chief complaint (49.3\%) followed by fluor albus (46.4\%). Severe pruritus seems to be more associated with $C$. albicans VVC but there was no significant different compared to $C$. non albicans. ( $p>0.05$, OR 2.29, 95\% CI 0.41-32.62).

Among fifty-six subjects $(81.2 \%)$ who had a husband or sexual partner, four $(5.8 \%)$ reported that their partner also had pruritus and erythema at the gland penis. One married subject did not have a husband/sexual partner anymore. Subjects who had a husband or sexual partner with erythema and pruritus at the gland penis seemed to have a greater tendency to get C. non-albicans infection. (p > 0.05, OR 6.40, 95\% CI $0.51-174.56)$.

Most of the subjects had pruritus and fluor albus for less than 1 year (91.3\%). Those with duration of illness more than 1 year tend to have $C$. non-albicans VVC. (OR 3.42, 95\% CI 0.41-32.62).

We found no relationship between subjects with $C$ non-albicans VVC with history of recurrent illness of more than 4 times during the last 1 year and those who had already been treated by antifungal. 
Table 2. History of illness and subjective findings

\begin{tabular}{|c|c|c|c|c|c|c|}
\hline & $\frac{\text { C. albicans }}{\mathrm{n}(\%)}$ & $\begin{array}{c}\text { C. non- } \\
\text { albicans } \\
\mathrm{n}(\%)\end{array}$ & $\begin{array}{c}\text { Mixed } \\
\mathrm{n}(\%)\end{array}$ & $\mathrm{n}(\%)$ & $\mathrm{p}$ & OR; CI 95\% \\
\hline \multicolumn{7}{|l|}{ Chief complaint } \\
\hline Pruritus & $25(73.5)$ & $7(20.6)$ & $2(5.9)$ & $34(49.3)$ & & \\
\hline Fluor albus & $16(50.0)$ & $13(40.6)$ & $3(9.4)$ & $32(46.4)$ & & \\
\hline Pruritus & 39 & 17 & 5 & & 0.2359 & $2.29(0.41-12.79)$ \\
\hline Partner's symptom & $1(25.0)$ & $3(75.0)$ & 0 & $4(5.8)$ & 0.1200 & $6.40(0.51-174.56)$ \\
\hline Duration > 1 year & $2(33.3)$ & $3(50.0)$ & $1(16.7)$ & $6(8.7)$ & 0.1939 & $3.42(0.41-32.62)$ \\
\hline \multicolumn{7}{|l|}{ Previous illness } \\
\hline $1-3 \times$ / last 1 year & $13(72.2)$ & $4(22.2)$ & $1(5.6)$ & $18(26.1)$ & & \\
\hline$\geq 4 \mathrm{x} /$ last 1 year & $7(63.6)$ & $3(27.3)$ & $1(9.1)$ & 11(15.9) & 0.5252 & $0.72(0.09-5.72)$ \\
\hline \multicolumn{7}{|l|}{$\begin{array}{l}\text { Previous anti-mycotic } \\
\text { treatment }\end{array}$} \\
\hline Doctor/Health sevices & $16(69.6)$ & $5(21.7)$ & $2(8.7)$ & $23(33.3)$ & 0.5024 & $1.60(0.15-16.43)$ \\
\hline None & $4(66.7)$ & $2(66.7)$ & 0 & $6(8.3)$ & & \\
\hline
\end{tabular}

n, numbers; OR, Odds Ratio; CI, Confidence interval

Table 3 shows that the patients aged more than 45 years old (premenopausal) also seems to be related with $C$. non-albicans VVC. (OR 4.32, 95\% CI $0.60-$ 37.75). Subject with pregnancy and overweight tend to suffer $C$. albicans VVC more frequently. ( $\mathrm{p}>0.05$, RO $1.46,95 \%$ CI $0.35-6.47$ and $\mathrm{p}>0.05$, RO 1.61, $95 \%$ CI $0.13-43.89$, respectively).

Subjects with contraceptives devices tend to be infected by C. albicans VVC. ( $\mathrm{p}=0.0069$, OR 5.7, 95\% CI 1.3724.86). Meanwhile, non-hormonal contraceptive users have association with $C$. non-albicans VVC. (p>0.05, OR 5.0, 95\% CI $0.41-12.79$ ).

No significant statistical association between systemic antibiotics' and corticosteroids' user with $C$. nonalbicans VVC.

C. albicans is the most prevalent species found in the subjects with clinical symptoms of vulvar erythema, edema, erosion, ample and cheese-like appearance of the discharge, satellite lesions surrounding genitalial skin and sour odour. But no specific symptoms were noted on C. non-albicans VVC.

Table 3. Predisposing factors

\begin{tabular}{lcccccc}
\hline \multicolumn{1}{c}{$\begin{array}{c}\text { Predisposing } \\
\text { factors }\end{array}$} & \multicolumn{1}{c}{ C. albicans } & C. nonalbicans & Mix & $\begin{array}{c}\text { Total } \\
\mathbf{n}(\%)\end{array}$ & $\mathbf{p}$ & RO; CI (95\%) \\
\cline { 2 - 5 } Age > 45 year & $2(33.3)$ & $4(66.7)$ & 0 & $6(8.7)$ & 0.1050 & $4.32(0.60-37.75)$ \\
$\begin{array}{c}\text { Associated diseases } \\
\text { DM }\end{array}$ & $2(100)$ & 0 & 0 & $2(2.9)$ & & \\
TB & $3(100)$ & 0 & 0 & $3(4.3)$ & & \\
Pregnancy & $11(61.1)$ & $4(22.2)$ & $3(16.7)$ & $18(26.1)$ & 0.4031 & $0.68(0.15-2.85)$ \\
Contraceptive & & & & & & \\
$\quad$ Hormonal & $4(40.0)$ & $4(40.0)$ & $2(20.0)$ & $10(14.5)$ & & \\
$\quad$ Non-hormonal & $1(16.7)$ & $5(83.3)$ & 0 & $6(8.7)$ & 0.2378 & $5.0(0.26-179.03)$ \\
Weight & & & & & & \\
$\quad$ Underweight & $1(50.0)$ & $1(50.0)$ & 0 & $2(2.9)$ & 0.5899 & $0.54(0.01-21.40)$ \\
$\quad$ Normoweight & $28(62.2)$ & $15(33.3)$ & $2(4.4)$ & $45(65.2)$ & & \\
$\quad$ Overweight & $3(75.0)$ & $1(25.0)$ & 0 & $4(5.8)$ & 0.5677 & $1.66(0.13-44.99)$ \\
Antibiotics & $12(57.1)$ & $9(42.9)$ & 0 & $21(30.4)$ & 0.2317 & $0.52(0.15-1.76)$ \\
Corticosteroids & $2(50.0)$ & $2(50.0)$ & 0 & $4(5.8)$ & 0.3979 & $0.46(0.04-5.09)$ \\
\hline
\end{tabular}

n, numbers; OR, Odds Ratio; CI, Confidence interval 
Cheese-appearance discharge is more frequently found in C. albicans VVC. ( $>>0.05$, OR $2.13,95 \%$ CI 0.53-9.18). Negative Gram staining examination was found in $8.7 \%$.

\section{DISCUSSION}

We used CHROMagar Candida to isolate Candida spp. CHROMagar Candida is a new differential isolation medium, which allows identification of $C$. albicans and C. non-albicans, especially $C$. tropicalis, C. glabrata dan C. krusei, on the basis of their colour and appearance. ${ }^{12}$ Compared with the standard or conventional isolation methods, this method provide a quicker result within $24-48$ hours, simpler and easier. ${ }^{13-15}$ Multiple yeast species can be detected in one specimen more easily. ${ }^{14}$ The sensitivity and specificity of this method were also reported high. ${ }^{2}$

The majority of the subject is on childbearing age, and this is consistent with other studies. ${ }^{6-9}$ The relationship between $C$. non-albicans VVC with age, sexual activity, job and education is still unclear. Eventhough one previous study found a relation between $C$. glabrata VVC with low education level. ${ }^{16}$
Incidence of $C$. non-albicans VVC at dr. Cipto Mangunkusumo General Hospital (30.4\%) tends to increase, with $C$. glabrata being the most frequent. The same result has been reported on other studies. ${ }^{3,8,9}$

Several studies in other centers suggested that these infections were caused by an inappropriate use of antifungal. ${ }^{8-10}$ However, we failed to show this association in this study.

Severe pruritus seems to be associated with $C$. albicans infections. While husband/sexual partner's symptom tends to correlate with $C$. non-albicans VVC. Physical examination and culture from the partner should be performed to get a more reliable data.

We should consider about the recall bias since some data were obtained through history taking.

Recurrent VVC could be caused by relapse (due to the same organism which is temporally suppressed by anti fungal therapy) ${ }^{7,17}$ or reinfection ( from natural gastrointestinal source or sexual transmission). ${ }^{7,10,17,18}$ VVC patients can transmit the infection to her partner ${ }^{17,18}$ but, relationship between $C$. non-albicans infection and the partner's symptoms is not known.

Table 4. Objective finding of genitalia external, the surrounding skin and laboratory examination.

\begin{tabular}{|c|c|c|c|c|c|c|c|}
\hline \multirow{2}{*}{\multicolumn{2}{|c|}{ Objective findings }} & \multirow{2}{*}{$\begin{array}{c}\text { C. albicans } \\
\text { n }(\%) \\
\end{array}$} & \multirow{2}{*}{$\begin{array}{c}\text { C. non-albicans } \\
\mathrm{n}(\%) \\
\end{array}$} & \multirow{2}{*}{$\begin{array}{c}\text { Mix } \\
\mathrm{n}(\%) \\
\end{array}$} & \multirow{2}{*}{$\begin{array}{l}\text { Total } \\
\text { n(\%) } \\
\end{array}$} & \multirow{2}{*}{$\mathbf{p}$} & \multirow{2}{*}{ RO; CI (95\%) } \\
\hline & & & & & & & \\
\hline \multirow{2}{*}{ Erythema } & Mild & $14(60.9)$ & $6(26.1)$ & $3(13.0)$ & $23(33.3)$ & 0.6985 & $0.80(0.21-2.90)$ \\
\hline & Distinct & $26(61.9)$ & $14(33.3)$ & $2(4.8)$ & $42(60.9)$ & & \\
\hline & $20(66.7)$ & $8(26.7)$ & $2(6.7)$ & $30(43.5)$ & 0.5239 & $1.41(0.43-4.70)$ \\
\hline \multicolumn{2}{|l|}{ Erosion } & $13(65.0)$ & $6(30.0)$ & $1(5.0)$ & $20(29.0)$ & 0.8914 & $1.08(0.30-3.99)$ \\
\hline \multicolumn{8}{|l|}{ Discharge } \\
\hline \multicolumn{2}{|c|}{ No } & $1(100)$ & 0 & 0 & $1(1.4)$ & & \\
\hline \multicolumn{2}{|c|}{ Limited in vagina } & $28(59.6)$ & $17(36.2)$ & $2(4.3)$ & $47(68.1)$ & & \\
\hline \multicolumn{2}{|c|}{ Come out from vagina } & $14(66.7)$ & $4(19.0)$ & $3(14.3)$ & $21(30.4)$ & 0.2367 & $2.13(0.53-9.18)$ \\
\hline \multicolumn{8}{|c|}{ Consistency of discharge } \\
\hline \multicolumn{2}{|c|}{ Cheese-appearance } & $19(67.9)$ & $5(17.9)$ & $4(14.3)$ & $28(40.6)$ & 0.1139 & $2.53(0.69-9.69)$ \\
\hline \multicolumn{2}{|c|}{ No coagulated } & $24(58.5)$ & $16(39.0)$ & $1(2.4)$ & $41(59.4)$ & & \\
\hline \multicolumn{7}{|c|}{ Involvement of surrounding } & $1.13(0.26-5.13)$ \\
\hline \multicolumn{2}{|c|}{ Sour Odour } & $20(60.6)$ & $8(24.2)$ & $5(17.2)$ & $33(47.8)$ & 0.7011 & $1.40(0.18-10.64)$ \\
\hline \multicolumn{8}{|l|}{ Gram Stain } \\
\hline \multicolumn{2}{|c|}{ Positive } & $39(61.9)$ & $19(30.2)$ & $5(7.9)$ & $63(91.3)$ & 0.6491 & $1.03(0.12-7.47)$ \\
\hline \multicolumn{2}{|c|}{ Negative } & $4(66.7)$ & $2(33.3)$ & 0 & $6(8.7)$ & & \\
\hline
\end{tabular}

n, numbers; OR, Odds Ratio; CI, Confidence interval 
Subjects with VVC symptom lasting more than 1 year tend to have $C$. non-albicans infections. The same result was reported by Nyirjesy et al. ${ }^{10}$ But recurrent infections during the last one year did not seem to correlate with $C$. non-albicans VVC. Opposite finding was reported by Sobel et al. ${ }^{8}$ The cause of this difference is not well understood, but the infection pattern in different region might have influence the results.

It seems that $C$. non-albicans infection is related with age. Spinillo et al., likewise, found a tendency of $C$. glabrata infection in the patients of more than 38 years old, but not with other $C$. non-albicans. ${ }^{16}$ Pregnancy and overweight might be a predisposing factors for VVC, but there is no clear association with $C$. non-albicans $\mathrm{VVC}$. ${ }^{4,8}$

Non-hormonal contraceptive tends to associate with C. non-albicans VVC. Other studies, however, reported a higher incidence of $C$. albicans VVC among condom ${ }^{6}$ and intrauterine device user. ${ }^{16}$ We could not find any reasons for this microbiological difference.

We did not find any specific symptoms associated with $C$. non-albicans VVC. Other study also found no characteristic differences between clinical symptoms of $C$. albicans and $C$. non-albicans infections. ${ }^{10}$ But Ryan et al. ${ }^{1}$ found that vulvar erythema and edema were associated with $C$ albicans VVC. ${ }^{1}$ Schaaf et. al. reported that $C$. albicans VVC is less frequently had unpleasant odor. ${ }^{19}$

Negative Gram staining in this study might be caused by technical problems, especially with $C$. glabrata infections, the only Candida spp that not produce pseudohypha. $^{8}$

We hope that the results of this study will drive the health providers to consider the possibility of $C$. nonalbicans infection, in the case of non responsiveness to conventional therapy. In such patients, species identification and resistancy test should be performed. ${ }^{20}$

From this study, we found that the proportion of $C$. non-albicans infection at dr. Cipto Mangunkusumo General Hospital, Jakarta, is $30.4 \%$, with C. glabrata as the most prevalent species.

No specific clinical symptoms were found in the subjects with $C$. non-albicans $\mathrm{VVC}$. We also found that $C$. non-albicans $\mathrm{VVC}$ infections are more common in women with age more than 45 years, using non-hormonal contraceptive, have a sexual partner with symptoms of erythema and pruritus on the glands penis, and a history of complaint for more than 1 year.

\section{Acknowledges}

Our deepest gratitude to dr. Kusmarinah Bramono, SpKK, DR. dr. Retno Wahyuningsih, MS, Dra. Mulyati, MS. and dr. Wresti Indriatmi, SpKK. M. Epid for their support through out the study.

\section{REFERENCES}

1. Ryan CA, Courtols BN, Hawes SE, Stevens CE, Eschenbad DA, Holmes KK. Risk assessment, symptoms and signs as predictors of vulvovaginal and cervical infections in an urban us STD clinis : implications for use of STD Algorithm. Sex Transm Inf. 1998; 74(Suppl I): S59-S76.

2. Houang ETS, Chu KC, Koehler AP, Cheng AFB. Use of CHROMagar Candida for genital specimens in the diagnostic Laboratory. J Clin Pathol 1997; 50:563-5.

3. Sobel JD. Vaginitis. N E J M 1997; 337(26): 1896-903.

4. Bingham JS. What to do with the patients with recurrent vulvovaginal candidiasis. Sex Transm Inf 1999; 75: 225-7.

5. Granger SE. The etiology and pathogenesis of vaginal candidosis. An update. Brit J Clin Practice 1992; 46(4):1-2.

6. El-din SS, Reynolds MT, Ashbee HR, Barton RC, Evans EGV. An investigation into the pathogenesis of vulvovaginal candidosis. Sex Transm Inf 2001; 77: 179-83.

7. Eckert LO, Hawes SE, Stevens CE, Kootsky LA, Eschenbach DA, Holmes KK. Vulvovaginal candidiasis. Clinical manifestations, risk factors, and management algorithm. Obstet Gynecol 1998; 82: 757-65.

8. Sobel JD dkk. Vulvovaginal candidiasis. Epidemiologic, diagnostic and therapeutic considerations. Am J Obstet Gynecol 1998; 178: 203-11.

9. Parazzini F, Di Cintio E, Chiantera V, Guaschino S. Determinants of different candida species infections of the genital tract in women, sporachrom study group. Eur J Obstet Reprod Biol 2000; 93(2): 141-5.

10. Nyirjesy P, Seeney SM, Terry Grody MH, Jordan CA, Buckley HR. Chronic fungal vaginitis: The value of cultures. Am J Obstet Gynecol 1995; 173: 820.

11. Ringdahl EN. Treatment of recurrent vulvovagina candidiasis. Am Fam Physician 2000;61(11):3306-17.

12. Odds FC, Bernaerts. CHROMagar Candida, a new diffential isolation medium for presumptive identification of clinically important Candida species. J Clin Microbiol 1994: 1923-9.

13. Pfaller MA, Houston A, Coffmann S. Application of CHROMagar Candida for rapid screening of clinical speciments for Candida Albicans, Candida tropicalis, 
Candida krusei and Candida (Torulopsis) glabrata. J Clin Microbiol 1996; 34: 58-61.

14. Jabra-Rizk MA, Brenner TM, Tomagnoli M, Baqui AAMA, Merz WG, Falkler WA Jr, Meiller TF. Evaluation of a reformulated CHROMagar Candida. J Clin Microbiol, 2001; 39: 2015-6.

15. Anson JJ, Nilen KD. Evaluation of CHROMagar Candida medium for the isolation and direct identification of yeasts species from the female genital tract Br. J Biomed Sci 1997; 54:237-9.

16. Spinillo A, Capuzzo E, Egbe TO, Baltaro F, Nicola S, Piazzi G. Torulopsis Glabrata Vaginitis. Obstet Gynecol 1995; 85-993-8.
17. Horowitz BJ, Edelstein SW, Lippman L. Sexual transmission of candida. Obstet Gynecol 1987; 69: 8836.

18. Suprihatin SD. Candida dan kandidiasis pada manusia. Jakarta, Faculty of Medicine, University of Indonesia, 1982.

19. Schaaf VM, Perez-Stable EJ, Borchard K. The limited value of symptoms and signs in the diagnosis of vaginal infections. Arch Intern Med 1990; 150: 1929-33.

20. Bille J. When Should Candida Isolates be Tested for Susceptibility to Azole Antifungal Agents ? Eur J Clin Microbiol Infect Dis 1997; 16:281-2. 
